\title{
Effects of water bugs on crustacean zooplankton in a shallow littoral zone
}

\author{
Wojciech Płaska* and Tomasz Mieczan \\ Department of Hydrobiology and Protection of Ecosystems, University of Life Sciences, Dobrzańskiego 37, 20-262 Lublin, Poland
}

\begin{abstract}
Interactions within the food chain are essential to ecosystem ecology. At the same time, very little is known of the trophic relationships between Heteroptera and zooplankton. The aim of this study was to examine the community structure of water bugs in the littoral zone of shallow lakes and their impact on crustacean zooplankton communities. A study on the effect of Heteroptera on zooplankton communities was carried out in the conditions of a laboratory experiment with two treatments: (1) aquariums in which the Heteroptera species Ilyocoris cimicoides and Plea minutissima were present (control treatment) and (2) aquariums from which Heteroptera were removed (removal treatment). The decisive factor in reducing the number of crustacean zooplankton was most likely the presence of predatory Heteroptera in a composition typical of the shallow littoral of eutrophic lakes. Their impact is reflected in both a decrease in the species richness and abundance of crustaceans and a transformation of the size structure of the zooplankton. The results of the study are the first to suggest a substantial seasonal impact of water bugs on crustacean zooplankton in a shallow lake. The results of the experiments confirm that predatory Heteroptera exert considerable pressure on crustacean zooplankton during the spring and summer peaks in abundance.
\end{abstract}

Keywords: Water bugs / crustacean zooplankton / shallow lake / land-water contact zone

Résumé - Effets des punaises d'eau sur le zooplancton crustacéen dans une zone littorale peu profonde. Les interactions au sein de la chaîne alimentaire sont essentielles à l'écologie des écosystèmes. En même temps, on sait très peu de choses sur les relations trophiques entre les hétéroptères et le zooplancton. L'objectif de cette étude était d'examiner la structure des communautés des punaises d'eau dans la zone littorale de lacs peu profonds et leur impact sur les communautés de zooplancton crustacéen. L'étude sur l'effet des hétéroptères sur les communautés zooplanctoniques a été réalisée dans les conditions d'une expérimentation en laboratoire avec deux traitements: (1) aquariums dans lesquels étaient présentes les espèces d'hétéroptères Ilyocoris cimicoides et Plea minutissima (traitement témoin) et (2) aquariums dont les hétéroptères ont été enlevés (traitement de retrait). Le facteur déterminant dans la réduction du nombre du zooplancton crustacéen a été très probablement la présence d'hétéroptères prédateurs dans un assemblage typique du littoral peu profond des lacs eutrophes. Leur impact se traduit à la fois par une diminution de la richesse et de l'abondance des crustacés et par une transformation de la structure en taille du zooplancton. Les résultats de l'étude sont les premiers à suggérer un impact saisonnier important des punaises d'eau sur le zooplancton crustacéen dans un lac peu profond. Les résultats des expériences confirment que les hétéroptères prédateurs exercent une pression considérable sur le zooplancton crustacéen pendant les pics d'abondance printanier et estival.

Mots-clés : Punaise d'eau / zooplancton crustacéen / lac peu profond / interface terre-eau

\section{Introduction}

The littoral zone in shallow lakes comprises a mosaic of vertical and horizontal microhabitats provided by macrophytes.

\footnotetext{
*Corresponding author: wojciech.plaska@up.lublin.pl
}

These habitats are part of a highly complex structure, including submerged vegetation and the shape of the lake basin, which create spatial differentiation in the water/land contact zone. This zone provides habitats enabling a different species composition of aquatic invertebrates from that found in the lake, due to the occurrence of different habitats (water and land) side by side (Naiman and Decamps, 1997). A shallow littoral zone covered 
by aquatic vegetation is often the site of concentrations of plankton in shallow lakes (Burks et al., 2002; Geraldes and Boavida, 2004; Bogacka-Kapusta, 2007; Basińska et al., 2009). However, the coastal zone is also an attractive microsphere for predatory invertebrate macrofauna, which may exert considerable pressure on assemblages of other macroinvertebrates, zooplankton, and even juvenile fish (Louarn and Cloarec, 1997; Kopp et al., 2006; Boda and Csabai, 2009; Klečka and Bourkal, 2012).

Water bugs are a group of organisms characteristic of the land/water zone. They are present in large numbers in the shallow littoral of eutrophic lakes and small water bodies (Savage, 1989). This zone is usually difficult to access for fish, and then species of predatory Heteroptera often constitute a group of consumers. Hence it seems that by feeding on small invertebrates, Heteroptera can exert a significant effect on the abundance of crustacean zooplankton. Literature data indicate that crustaceans may use this zone as a potential refuge offering protection against pressure from fish. Heteropteran predators are active swimmers and are able to penetrate even very shallow water (depth less than $1 \mathrm{~cm})$. They are able to exert considerable pressure on other aquatic invertebrates, macroinvertebrates and small fish, because they are present in large numbers and relatively large biomass. They are unique predators that are able to reach planktonic crustaceans assembled in the small depths in the littoral (Louarn and Cloarec, 1997; Blaustein, 1998; Eitam and Blaustein, 2004, 2010). Previous research has mainly focused on the effect of the physical and chemical properties of water on the occurrence of water bugs (Dias-Sylvia et al., 2010; Mieczan et al., 2014; Płaska and Tarkowska-Kukuryk, 2014; Płaska et al., 2016). There is still little information, however, on the effect of food abundance on the occurrence of Heteroptera, or on the trophic relationships in the predatorprey (water bugs and zooplankton) system. Such information can be found in only a few works (Dieguez and John, 2003; Klečka and Bourkal, 2012, 2013). These, however, have focused on predation by only one Heteroptera family, the Notonectidae, mainly in the context of predation on Culicidae larvae (Dieguez and John, 2003; Eitam and Blaustein, 2004; Saha et al., 2008; Eitam and Blaustein, 2010). As water bugs are abundant in the shallow littoral of lakes (Płaska, 2012), it therefore seems that they may play an important role in shaping the qualitative and quantitative structure of zooplankton. On the other hand, as Heteroptera exhibit pronounced seasonal changes in abundance and taxonomic composition (literatura), it seems that their pressure may vary between seasons. Literature data indicate that this group usually has two peaks in numbers - in spring and in early autumn (Wróblewski, 1980; Płaska, 2012). The main objective of the study was to determine the following: (i) the structure of Heteroptera in the water/land contact zone of shallow eutrophic lakes, taking into account seasonal variation in the species composition of predatory Heteroptera; (ii) the effect of this structure on the abundance of planktonic crustaceans (top-down regulation) in the conditions of a laboratory experiment during the peaks of Heteroptera abundance (in spring and autumn).

\section{Materials and methods}

\subsection{Study area}

Water bugs and zooplankton communities were examined in the shallow littoral zone of two eutrophic lakes, Miejskie and Skomielno (Łęczna-Włodawa Lakeland, eastern Poland). The area of Miejskie Lake is 45.4 ha and its maximum depth is $2.2 \mathrm{~m}\left(51^{\circ} 30^{\prime} 18^{\prime \prime} \mathrm{N}, 22^{\circ} 52^{\prime} 50^{\prime \prime} \mathrm{E}\right)$. The vegetation of the land/ water contact zone is dominated by Ceratophyllum demersum, Hydrocharis morsus-ranae, Lemna minor and Carex sp. At a depth of $0.5 \mathrm{~m}$, Phragmites australis and Potamogeton crispus were dominant. The area of Skomielno Lake is 74.3 ha and its maximum depth is $5.5 \mathrm{~m}\left(51^{\circ} 29^{\prime} 28^{\prime \prime} \mathrm{N}, 23^{\circ} 1^{\prime} 3^{\prime \prime} \mathrm{E}\right)$ (Harasimiuk et al., 1998). C. demersum, H. morsus-ranae and Carex sp. were dominant in the contact zone. At a depth of $0.5 \mathrm{~m}$, Sparganium ramosum and Hottonia palustris were dominant.

\subsection{Sampling and identification of Heteroptera and zooplankton communities}

Sampling was done four times in 2016, once every two months from May to November. Samples were taken from two microhabitats: the land/water contact zone (max. depth $0.05 \mathrm{~m})$ and among emergent macrophytes (max. depth $0.5 \mathrm{~m}$ ) (Fig. 1). Each time, 3 samples were collected from each site. In each type of micro-habitat and on each sampling day water bugs were sampled using a metal frame $\left(0.5 \mathrm{~m} \times 0.5 \mathrm{~m}-0.25 \mathrm{~m}^{2}\right)$ and their abundance was calculated per $\mathrm{m}^{2}$ of bottom surface. One sample was analysed alive and two samples were preserved immediately with $80 \%$ alcohol. The abundance of crustacean zooplankton and their community composition were determined by the Utermöhl method (Utermöhl, 1958). Three samples $10 \mathrm{~L}$ were filtered through a plankton net with $0.25 \mathrm{~mm}$ mesh size. Crustacean samples (whole one sample $=$ $100 \mathrm{ml}$ ) were sedimented for $24 \mathrm{~h}$ in a cylinder stoppered with Parafilm, and then the upper volume of $20 \mathrm{ml}$ was gently removed. Morphological identification of water bugs and zooplankton was mainly based on works by Wróblewski (1980); Savage (1989); Błędzki and Rybak (2016).

\subsection{Laboratory experiments}

A laboratory experiment using intact natural communities can help to identify the various effects of water bugs on crustacean communities. The experiment was performed in two periods: spring (May) and autumn (September) 2016. The water from the land/water contact zone containing zooplankton, suspended solids and phytoplankton was transported to the laboratory. The study on the trophic relationships between water bugs and planktonic crustaceans included the following experimental treatments: (1) Aquariums containing zooplankton and predatory water bugs (Heteroptera present) - control treatment; (2) Aquariums containing only zooplankton, from which Heteroptera were removed - removal treatment.

For each experimental treatment, the study was conducted in three aquariums. The aquariums were $0.25 \mathrm{~m}^{2}$ in area. They 


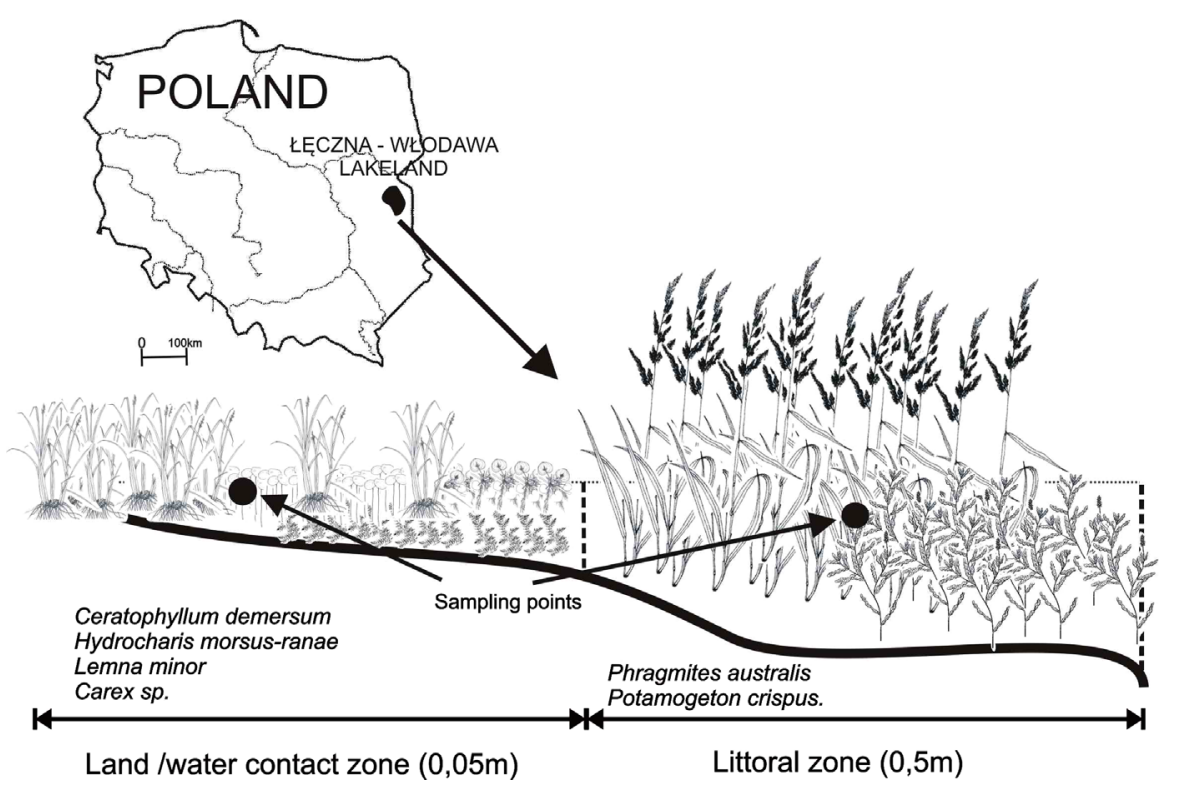

Fig. 1. Localization of the study sites in the investigated lakes.

were filled with water containing plankton to a depth of $10 \mathrm{~cm}$. Aquatic vegetation of a composition similar to that of the land/ water littoral zone was placed in them as well. Both the water with the plankton, water bugs and vegetation (H. morsus-ranae and $C$. demersum) and the bottom sediment were collected from the water/land zone of the lakes. Predatory water bugs caught in the lake were separated live from the samples and carefully moved to an aquarium with a habitat corresponding to the natural conditions in the littoral zone (Ilyocoris cimicoides -4 ind. and Plea minutissima - 3 ind. in each experimental aquarium (Heteroptera Present). All the aquariums were set up for one day to stabilize the habitat conditions before the experiment was begun. Throughout the duration of the laboratory experiment, i.e. for 7 days, $100-\mathrm{ml}$ samples were taken from all aquariums and preserved with Lugol's solution for zooplankton analysis. Samples were taken in 3 replicates from each aquarium. For all sampling times combined, a total of 63 samples from the control treatment and 63 samples from the removal treatment were taken. After 24-hour sedimentation, quantitative analysis of the material was performed using a Nikon SMZ800 stereomicroscope at maximum magnification of $120 \times$. Crustaceans were further analysed in terms of size classes: small - up to $0.5 \mathrm{~mm}$, medium - from 0.6 to $0.9 \mathrm{~mm}$, and large $-1 \mathrm{~mm}$ and larger.

\subsection{Data analyses}

Statistical analyses were performed using Statistica 6.0 software. First, the normality of the data distribution was checked by the Kolmogorov-Smirnov test. The influence of sampling dates was checked by analysis of variance (ANOVA). Pearson's correlations were used to examine the relationship between zooplankton communities and potential grazing pressure (abundance of water bugs).

\section{Results}

\subsection{Water bugs and crustacean communities - field study}

Altogether 18 species of Heteroptera aquatica were found in the lakes. Differences in the numbers of water bugs between zones of the lakes were statistically significant (Skomielno Lake ANOVA, $F=9.9, P<0.005$, Miejskie Lake ANOVA, $F=17.77, P<0.001)$. The Heteroptera community structure in the two lakes was similar and generally dominated by $I$. cimicoides (L.) (more than $40 \%$ of total abundance) and $P$. minutissima Leach, which accounted for more than $20 \%$ of the total abundance (Fig. 2). Water bug abundance was characterized by spring-autumn maxima. The average abundance of dominant bugs in the land/water zones was 22 ind. $\mathrm{m}^{-2}$ for I. cimicoides and 8 ind. $\mathrm{m}^{-2}$ for P. minutissima in Skomielno Lake, and 16 ind. $\mathrm{m}^{-2}$ for I. cimicoides and 7 ind. $\mathrm{m}^{-2}$ for P. minutissima in Miejskie Lake (Fig. 3).

Differences in the numbers of zooplankton were significantly higher in the land/water zone $(0.05 \mathrm{~m})$ than in the shallow littoral zone $(0.5 \mathrm{~m})$ (Skomielno Lake ANOVA, $F=16.6, P<0.001$, Miejskie Lake ANOVA, $F=48.1, P$ $<0.001)$. The crustacean zooplankton community in both lakes was dominated by nauplii (29\%), Alona sp. (12\%), Ceriodaphnia sp. (10\%) and Macrocyclops albidus (9\%), which contributed $60 \%$ of the total zooplankton numbers. Higher abundance of crustacean communities (270-330 ind. $\mathrm{dm}^{-3}$ ) was noted in the land/water zone than in the greater depths in Skomielno Lake.

The highest abundance of water bugs in both lakes was observed in the early summer (May) in the water/land contact zone, and ranged from 63 to 80 ind. $\mathrm{m}^{-2}$. In the zooplankton community, maximum abundance was noted in the spring in the water/land zone, with $270-330$ ind. $\mathrm{dm}^{-3}$. In subsequent months, 


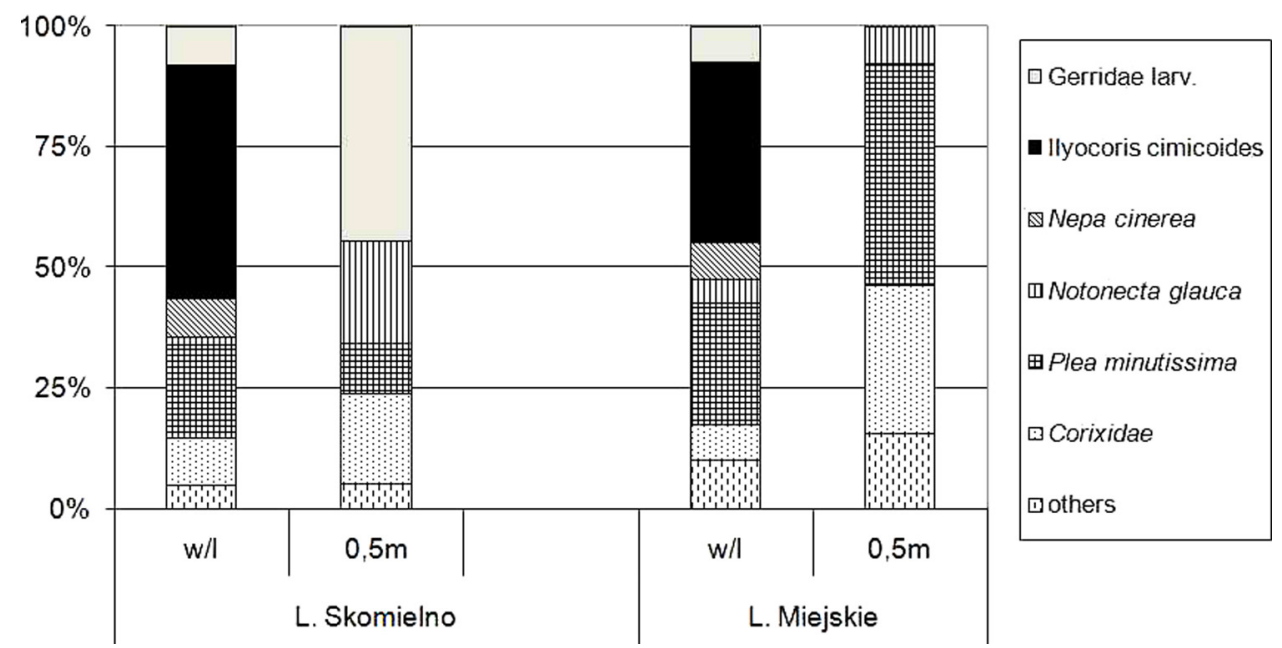

Fig. 2. Percentage abundance of water bugs in the investigated lakes.
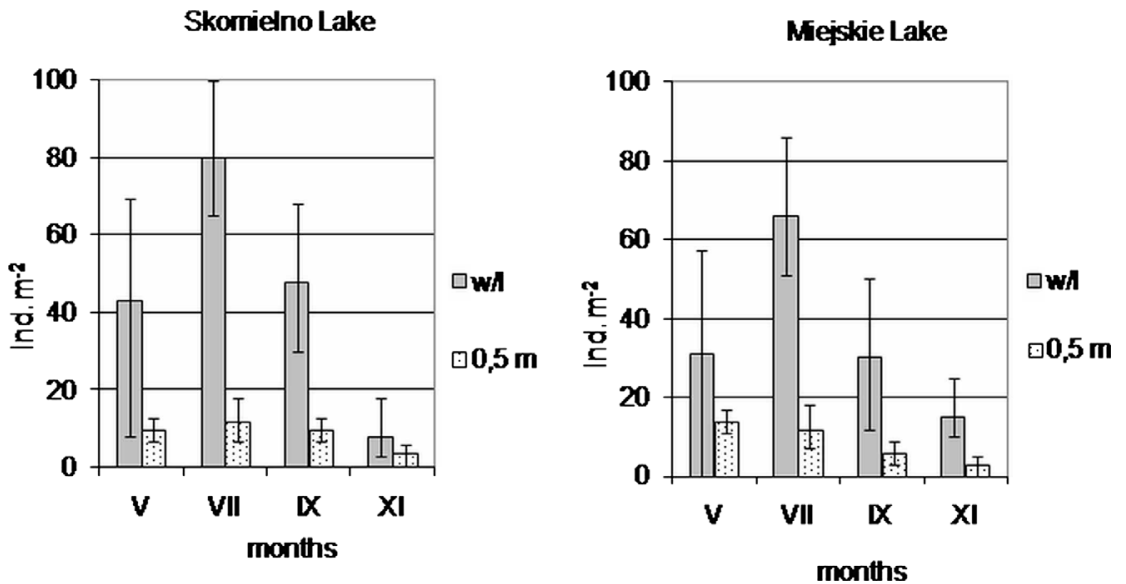

Fig. 3. Density of water bugs in the investigated lakes ( $\mathrm{I} \pm$ standard deviation).

the abundance of planktonic crustaceans sharply decreased, and in November it did not exceed 40 ind. $\mathrm{dm}^{-3}$ ( Fig. 4).

\subsection{Laboratory experiments}

During the experiments, two consecutive stages in zooplankton were observed. The start of the first experiment (May) was characterized by the dominance of copepods, with a large contribution of nauplii $(60 \%)$ and Eucyclops macruroides $(21 \%)$. In the second experiment (September), the zooplankton community was dominated by nauplii (34\%), Macrocyclops albidus (18\%), M. fuscus (15\%), Ceriodaphnia sp. (14\%) and Alona sp. (13\%).

During the experiments in May and September a significant decrease in the total number of planktonic crustaceans was recorded in all control treatment aquariums. At the beginning of the experiment in May, the abundance of zooplankton was significantly higher than in September (ANOVA $F=12.6, P<0.001$ ). The average decline in numbers during the 7 days of the experiment was $60 \%$ in May (initial abundance 353 ind. $\mathrm{dm}^{-3}$, final abundance 140 ind. $\mathrm{dm}^{-3}$ ) and $75 \%$. In September (initial abundance 230 ind. $\mathrm{dm}^{-3}$, final abundance 47 ind. $\mathrm{dm}^{-3}$ ) (Fig. 5A, B,
Fig. 6A, B). On the seventh day of the experiment in September, the decline in abundance was $62 \%$ (to 82 ind. $\mathrm{dm}^{-3}$ ), which was almost the same as in May over the same period. In the removal treatment aquariums, the average zooplankton abundance decreased by $32 \%$ in May (from 300 to 205) while in September it did not change significantly during the experiment (from 235 on day 1 to 220 ind. $\mathrm{m}^{-3}$ on day 7) (Figs. 5B, B). Irrespective of the study period, the data analysis indicated a strong positive relationship between the abundance of water bugs and zooplankton. In the control treatment, abundance of Heteroptera showed a strong positive correlation with the abundance of zooplankton $(r=0.48$, $P<0.01)$.

In terms of the size class structure of the planktonic crustaceans in the control treatment aquariums, the greatest average decline was noted for the class of large crustaceans, amounting to $74 \%$ on average, while the decline among small crustaceans was $51 \%$ and the average number of medium-sized individuals remained stable. In the removal treatment aquariums, the average abundance of small crustaceans decreased by $44 \%$ and that of medium-sized crustaceans by $17 \%$, while large ones remained relatively stable (decline of $5 \%)$. 

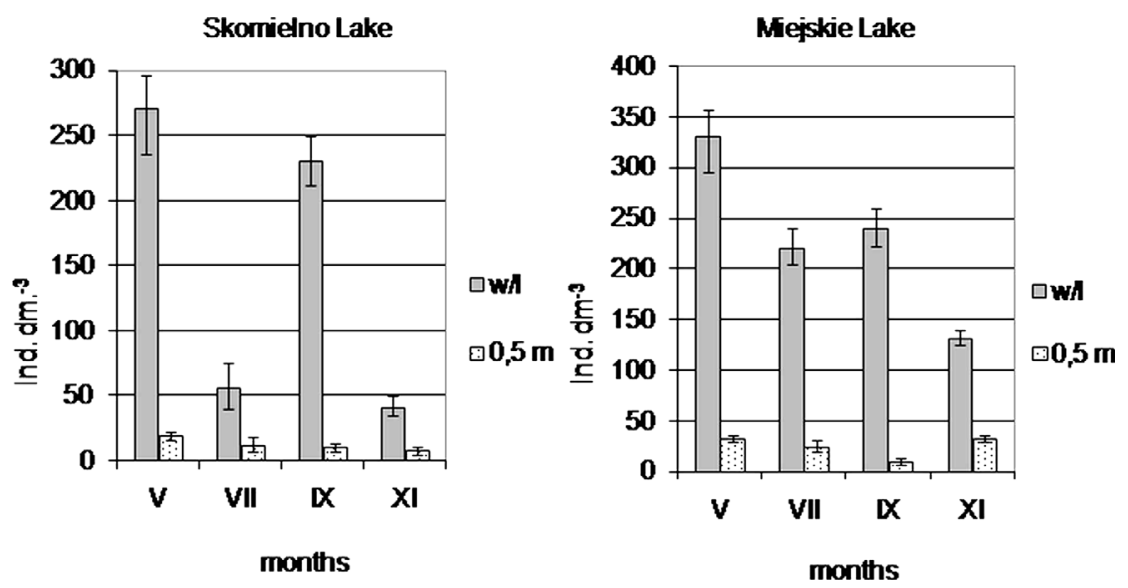

Fig. 4. Density of crustacean zooplankton in the investigated lakes ( \pm standard deviation).

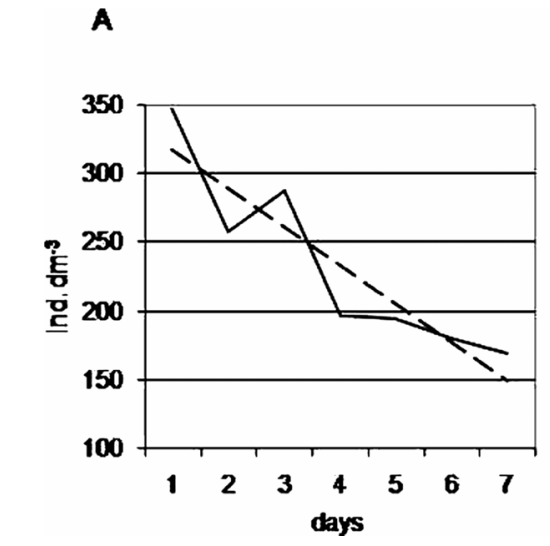

B

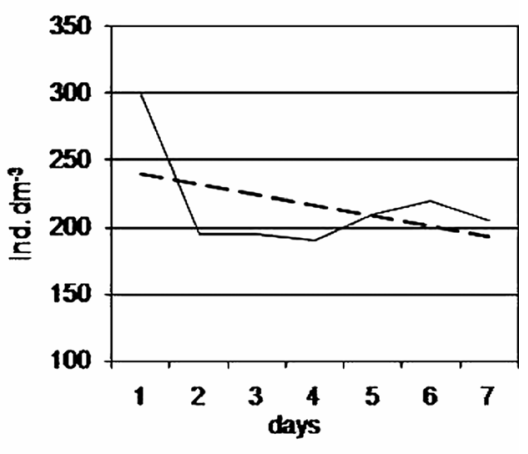

Fig. 5. Mean density of crustacean zooplankton in control (A) and removal (B) treatments in May.
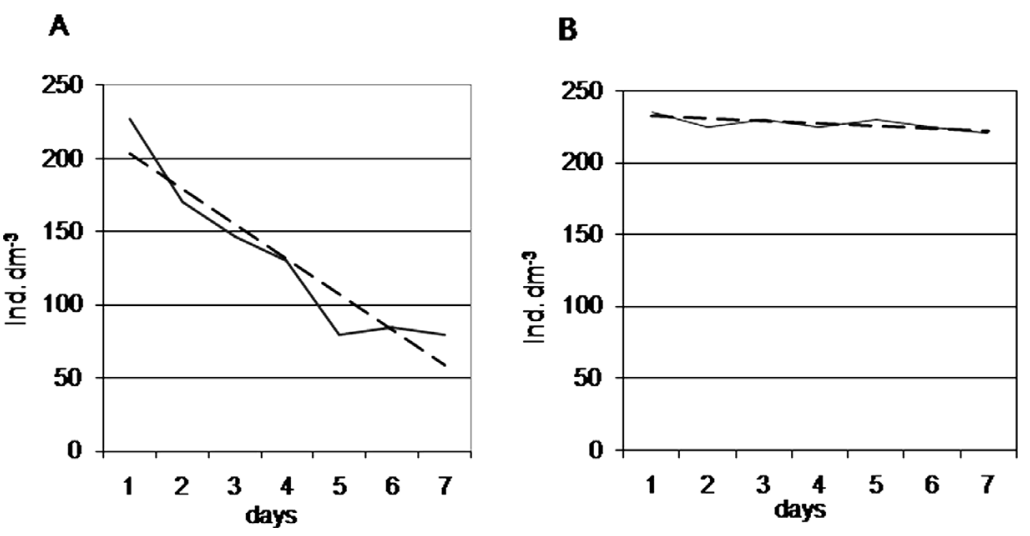

Fig. 6. Mean density of crustacean zooplankton in control (A) and removal (B) treatments in September.

\section{Discussion}

The initial stage preceding the present study was a multi-year analysis of the taxonomic composition, density and distribution of aquatic Heteroptera in various trophic types of water bodies (Płaska, 2012; Mieczan et al., 2014; Płaska and TarkowskaKukuryk, 2014). That research showed that predatory species of Heteroptera are abundant in eutrophic lakes with shallows overgrown with vegetation. The number of identified taxa of water bugs and planktonic crustaceans is comparable with other studies examining the shallow littoral zone in eutrophic lakes (Lauridsen and Buenk, 1996; Burks et al., 2002; Tolonen et al., 2003). The number of planktonic crustacean species is generally higher in the littoral of the lake rather than in the pelagic zone, as confirmed by research (Kuczyńska-Kippen and Nagengast, 2006; Bogacka-Kapusta, 2007). The higher number of 
planktonic crustaceans is linked to the presence of refuges created by macrophytes. The highest number of species and the highest abundance occur in the emerged plants zone, and are slightly lower among submerged plants. Among emerged macrophytes, the number of planktonic crustaceans has been found to increase with plant density (Geraldes and Boavida, 2004; Basińska et al., 2009; Horpilla et al., 2009). Thus for our study we selected eutrophic lakes with a well-developed shallow littoral zone. In the present study, Heteroptera species characteristic of habitats with rich vegetation were observed, which is consistent with other studies (Burks et al., 2001; Bloech et al., 2010; Płaska, 2012; Turić et al., 2012, 2015). Also significant were the seasonal changes in the qualitative and quantitative structure of this group. The development cycle of Heteroptera usually involves two peaks in abundance, occurring in the spring and early autumn, as shown in the present study. Predatory pressure from Heteroptera on small invertebrates is greatest during these periods, which was reflected in the decrease in numbers of crustacean zooplankton. This pattern was also confirmed by the laboratory experiment. The Heteroptera used in the experiment are a crucial and typical element of littoral macrofauna, and hence the results of the experiment are indicative of the important role of all predatory insects in the shallow water of the littoral, especially in the water/land contact zone, in shaping the zooplankton population (Murdoch et al., 1984; Kopp et al., 2006; Klečka and Bourkal, 2012, 2013).

The results of the experiment clearly show that the number of zooplankton was significantly reduced in the aquariums with predatory water bugs as compared to the control aquariums with no predators. The reduction in the number of zooplankton was minimal in the removal treatment aquariums in both experimental cycles and should therefore be treated as the natural death rate in such conditions. The natural death rate in nature may be determined by diverse factors, such as food accessibility. In this experiment, some water was taken with the Heteroptera from the littoral zone of the lake in order to ensure a supply of natural feed (Savage, 1989; Błędzki and Rybak, 2016).

It should be noted that the literature contains little information on the importance of planktonic crustaceans as an element of the diet of predatory Heteroptera, while it is known that they can be their food. For this reason it was very difficult to determine the level of predation pressure exerted by Heteroptera on planktonic crustaceans in the shallow littoral. Previous observations have devoted much attention to the Notonectidae, which have a significant influence on the regulation of water invertebrates and even young fish and amphibians (Louarn and Cloarec, 1997; Kopp et al., 2006; Vandekerkhove et al., 2012). It has been demonstrated that they can be effective regulators of mosquitoes and help to control them, and that, if necessary, they can also feed on Chironomidae (Saha et al., 2008, 2010). As shown in small water bodies, they can regulate the abundance and diversity of the entire invertebrate population (including plankton), as confirmed by experiments similar to those presented in our study (Eitam and Blaustein, 2010). It is likely, however, that larger individuals are chosen first (Blaustein, 1998). A study conducted by Louarn and Cloarec (1997) also seems to confirm the hypothesis regarding the preference of Notonectidae for larger taxa, showing that Notonectidae were more effective than I. cimicoides at feeding on pike fry. Although I. cimicoides chose smaller prey, vertical migrations of crustaceans were observed as a response to predation by Notonectidae (Gilbert and Hampton, 2001), or migration into clumps of vegetation as a response to predation by Odonata (Burks et al., 2002).

The size of the prey as well as that of the predator is also a crucial factor. The predator must take into account the size of its prey, which largely determines its ability to defeat it. It also significantly influences the predator's choice of prey. This is described by the theory of optimal feeding (Schelby, 2014), according to which the predator chooses the largest possible prey from a wide size range because the energy required to hunt it will be less than the energy derived from eating it. The results of our experiment have confirmed this theory. Increased pressure on small and large planktonic crustaceans, with little pressure on the average size class, indicates that bugs consume the food available to them in natural littoral habitats. I. cimicoides, as a large taxon (about $40 \mathrm{~mm}$ ), chooses the largest victims available among the plankton, while the co-occurring $P$. minutissima attains a size of $2 \mathrm{~mm}$, so only small planktonic crustaceans remain within its range (Savage, 1989; Wróblewski, 1980).

Thus the functioning of the food web in the water/land contact zone seems to be distinctly different from that found in the pelagic zone. The numerous aquatic plants and low water depth here impede the access of fish to plankton, and for this reason crustaceans often concentrate in this microhabitat (Burks et al., 2001, 2002; Geraldes and Boavida, 2004), where invertebrate predators such as water bugs can effectively reduce the abundance of zooplankton. Other authors have confirmed that aquatic invertebrates can regulate the abundance of plankton in the case of limited feeding by fish (low depth, high macrophytes density or poor visibility) (Horpilla et al., 2009; Cobbaret et al., 2010). Hence zooplankton present in large numbers in the water/land zone may be a source of food for water bugs (Eitam and Blaustein, 2010).

Our study has shown that that not only the larvae of dragonflies (Burks et al., 2002) or Notonectidae (Eitam and Blaustein, 2010) but also other predatory Heteroptera species may influence zooplankton abundance and size structure in shallow, eutrophic reservoirs with abundant plants. To more comprehensively investigate the trophic relationship between water bugs and zooplankton, future research should take into account the potential food resources of both groups of organisms (algae, bacteria and protozoans).

\section{References}

Basińska AM, Cichocka M, Kuczyńska-Kippen N. 2009. The diurnal distribution of cladocerans in bed of Myriophyllum verticillatum in Lake Wielkowiejskie. Oceanol Hydrobiol Stud 38: 103-111.

Blaustein L. 1998. Influence of the predatory backswimmer, Notonecta maculata, on invertebrate community structure. Ecol Entomol 23: 246-252.

Błędzki LA, Rybak JI. 2016. Freshwater crustacean zooplankton of Europe: Cladocera and Copepoda (Calanoida, Cyclopoida). In: Key to species identification, with notes on ecology, distribution, methods and introduction to data analysis. Springer International Publishing, Switzerland, $933 \mathrm{p}$.

Bloechl A, Koenemann S, Philippi B, Melber A. 2010. Abundance, diversity and succession of aquatic Coleoptera and Heteroptera in a cluster of artificial ponds in the North German Lowlands. Limnologica 40: 215-225. 
Boda P, Csabai Z. 2009. Diel and seasonal dispersal activity patterns of aquatic Coleoptera and Heteroptera. Verh Int Ver Limnol 30: 1271-1274.

Bogacka-Kapusta E. 2007. Changes in the abundance, species richness, and size structure of zooplankton under the influence of environmental conditions in the shallow littoral zone of a heated lake. Arch Pol Fish 15: 335-351.

Burks RL, Jeppesen E, Lodge DM. 2001. Pelagic prey and benthic predators: impact of odonate predation on Daphnia. $J N A M$ Benthol Soc 20: 615-628.

Burks RL, Lodge DM, Jeppesen E, Lauridsen TL. 2002. Diel horizontal migration of zooplankton: costs and benefits of inhabiting littoral zones. Freshwater Biol 47: 343-365.

Cobbaret D, Bayley SE, Greter JL. 2010. Effects of a top invertebrate predator (Dytiscus alaskanus; Coleoptera: Dytiscidae) on fishless pond ecosystems. Hydrobiologia 644: 103-114.

Dias-Silva KH, Cabette SR, Juen L, De Marco P. 2010. The influence of habitat integrity and physical-chemical water variables on the structure of aquatic and semi-aquatic Heteroptera. Zoologia 27: 918-930.

Dieguez MC, John JG. 2003. Predation by Buenoa macrotibialis (Insecta, Hemiptera) on zooplankton: effect of light on selection and consumption of prey. J Plankton Res 25: 759-769.

Eitam A, Blaustein L. 2004. Oviposition habitat selection by mosquitoesInresponse to predator (Notonecta maculata) density. Physiol Entomol 29: 188-191.

Eitam A, Blaustein L. 2010. Effects of predator density and duration of predator occupancy on crustacean abundance and diversity in experimental pools. Hydrobiologia 652: 269-276.

Geraldes AM, Boavida MJ. 2004. Do littoral macrophytes influence crustacean zooplankton distribution? Limnetica 23: 57-64.

Gilbert JJ, Hampton SE. 2001. Diel vertical migrations of zooplankton in a shallow, fishless pond: a possible avoidanceresponse cascade induced by notonectids. Freshwater Biol 46: 611-621.

Harasimiuk M, Michalczyk M, Turczyński M. (Ed.) 1998. Jeziora Łęczyńsko-Włodawskie, Wyd UMCS. Lublin 176 p.

Horppila J, Eloranta P, Liljendahl-Nurminen A, Niemistö J, PekcanHekim Z. 2009. Refuge availability and sequence of predators determine the seasonal succession of crustacean zooplankton in a clay-turbid lake. Aquat Ecol 43: 91-103.

Klečka J, Boukal DS. 2012. Who eats whom in a pool? a comparative study of prey selectivity by predatory aquatic insects. Plos One 7: e37741.

Klečka J, Boukal DS. 2013. Foraging and vulnerability traits modify predator-prey body mass allometry: freshwater macroinvertebrates as a case study. J Anim Ecol 82: 1031-1041.

Kopp K, Wachlevski M, Eterovick PC. 2006. Environmental complexity reduces tadpole predation by water bugs. Can J Zool 84: $136-140$

Kuczyńska-Kippen N, Nagengast B. 2006. The influence of the spatial structure of hydromacrophytes and differentiating habitat on the structure of the rotifer and cladoceran communities. Hydrobiologia 559: 203-212.
Lauridsen TL, Buenk I. 1996. Diel changes In the horizontal distribution of zooplankton in the litoral zone of two shallow eutrophic lakes. Arch Hydrobiol 137: 79-88.

Louarn HL, Cloarec A. 1997. Insect predation on pike fry. J Fish Biol 50: $366-370$

Mieczan T, Tarkowska-Kukuryk M, Płaska W, Rechulicz J. 2014. Abiotic predictors of faunal communities in an ombrotrophic peatland lagg and an open peat bog. Isr J Ecol Evol 60: 62-74.

Murdoch W, Scott MA, Ebsworth P. 1984. Effects of the general predator, Notonecta (Hemiptera) upon a freshwater community. $J$ Anim Ecol 53: 791-808.

Naiman RJ, Decamps H. 1997. The ecology of interfaces: riparian zones. Annu Revi Ecol Syst 28: 621-658.

Płaska W. 2012. Zonality in occurring of zoopleuston in two eutrophic lakes on Łęczna-Włodawa Lakeland. Teka Kom Ochr Kształ Sr Przyr 1: 173-180.

Płaska W, Tarkowska-Kukuryk M. 2014. Influence of abiotic factors on species spectrum of zoopleuston in different types of peatlands. Pol J Enviro Stud 23: 441-447.

Płaska W, Kurzątkowska A, Stępień E, et al. 2016. The effect of dredging of a small lowland river on aquatic Heteroptera. Ann Zool Fennici 53: 139-153.

Saha N, Aditya, G, Bal A, Saha GK. 2008. Influence of light and habitat on predation of Culex quinquefasciatus (Diptera: Culicidae) larvae by the waterbugs (Hemiptera: Heteroptera). Insect Sci 15: 461-469.

Saha N, Aditya G, Goutam K. Saha S, Hampton E. 2010. Opportunistic foraging by heteropteran mosquito predators. Aquat Ecol 44: 167-176.

Savage AA. 1989. Adults of the British aquatic Heteroptera: a key with ecological notes. Freshwater Biological Association, Ambleside, $173 \mathrm{p}$.

Shelby DG. 2014. Feeding ecology of fish. Elsevier, San Diego, 416 p.

Tolonen KT, Hämäläinen H, Holopainen IJ, Mikkonen K, Karjalainen J. 2003. Body size and substrate association of littoral insect in relation to vegetation structure. Hydrobiologia 499: 179-190.

Turić N, Merdić E, Hackenberge BK, Jelićić Ž, Vignjević G, Csabai Z. 2012. Structure of aquatic assemblages of Coleoptera and Heteroptera in relation to habitat type and flood dynamic structure. Aquat Insect 34: 189-205.

Turic N, Temunovic M, Radovic A, Vignjevic G, Bogojevic MS, Merdic E. 2015. Flood pulses drive the temporal dynamics of assemblages of aquatic insects (Heteroptera and Coleoptera) in a temperate floodplain. Freshwater Biol 60: 2051-2065.

Utermöhl H. 1958. Zur Vervollkommnung der quantitativen Phytoplankton-Methodik. Mitt. int. Ver Limnol 9: 1-38.

Vandekerkhove J, Namiotko T, Hallmann E, Martens K. 2012. Predation by macroinvertebrates on Heterocypris incongruens (Ostracoda) in temporary ponds: impacts and responses. Fund Appl Limnol 181: 39-47.

Wróblewski A. 1980. Fauna słodkowodna Polski. Pluskwiaki (Heteroptera). PWN, Warszawa-Poznań, 157 p. 